\title{
The violence of the masculine ideal: A case for nomadic masculinities
}

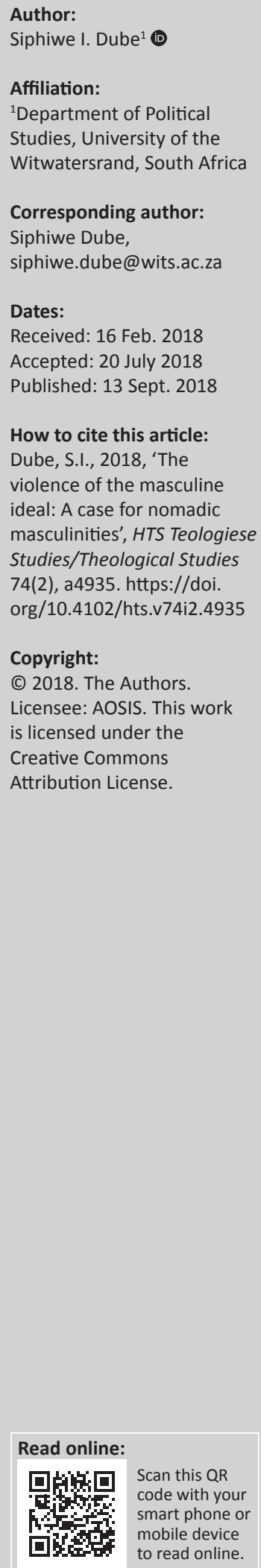

\begin{abstract}
In this article, I argue that a different kind of discourse on Christian masculinities in postapartheid South Africa is possible despite the prevalence of largely idealised and politically conservative ideologies of masculinities promoted primarily through the public and private performance of violent masculinities. Drawing on a redacted critique of current prevalent discourses of transformation in critical masculinities studies such as alternatives masculinities, hegemonic masculinities, liberated masculinities and toxic masculinities, I underscore how these discourses are limited in their thinking on masculinities in general as they presume the ideal of what a liberated man should be like. Specifically, I argue that idealised masculine ideals, even in their liberatory forms, eschew mobility and fluidity and, therefore, end up restricting the possibility for transformative action. I propose, instead, that we reinscribe discourses of Christian masculinities with the notion of nomadic subjectivity, espoused by Rosi Braidotti, as a form of transpositional praxis of being in order to expand our linguistic repertoire of transformative masculinities. Such a shift in focus, as I demonstrate, has the propensity to aid us in constructing and implementing creative and imaginative programmes of engaging men in rethinking scripts of masculinities.
\end{abstract}

\section{Introduction}

The nomadic subject is a myth, that is to say a political fiction, that allows you to think through and move across established categories and levels of experience: blurring boundaries without burning bridges. Implicit in [the choice of this figuration] is the belief in the potency and relevance of the imagination, of myth-making, as a way to step out of the political and intellectual stasis of these postmodern times. (Braidotti 1994:4)

Undoubtedly, some of the harshest forms of hegemonic exclusionary practices of subjectivity have been enacted, unfortunately, through Christian theological discourses, despite the religion's ideal self-imagination as inclusive and against repression. To the end of representing and challenging these exclusions in terms of gender, and with particular reference to the treatment of women within Christian theologies, multiple forms of feminisms and, lately, critical masculinities have put forth re-imagined scripts of being in opposition to the prescriptive and proscriptive definitions of the Christian tradition with respect to related concepts of how we should be as gendered religious beings. In general, according to this critical scholarship, the argument is that what concepts of religious being such as 'the tradition' tend to reflect is a desire for fixity and impermeable boundaries rather than the openness and fluidity of the Christian message. Here, one can point to the work of various African women theologians who have articulated the argument of engendering theology in various ways (Amoah 1997; Kanyoro \& Njoroge 1996; Njoroge \& Dube 2000; Oduyoye 1990; Oduyoye \& Kanyoro 1992; 2001; Phiri, Govinden \& Nadar 2002).

Without playing down the critical role of this feminist tradition and its contribution to challenging how we think about gender and theology, in this article, I focus on masculinities. Specifically, I argue that a different kind of discourse on religious masculinities in post-apartheid South Africa is needed in response to the prevalence of fixed and politically conservative Christian ideologies of masculinities promoted through both public and private performances of oppressive, toxic and exalted hegemonic masculinities on the one hand and largely idealised and static liberatory Christian discourses of masculinities on the other hand. Furthermore, the point is not to dismiss the critical scholarship on Christian masculinities that has come from scholars such as Du Pisani

Note: This article was originally delivered as a keynote address by the title 'The Violence of the Masculine Ideal: A Theological Praxis Concern' at the Annual Conference of the Society for Practical Theology in South Africa (SPTSA) - 'Reforming Practical Theological Anthropology with the Focus on Culture, Gender and Violence' - held at UNISA, Pretoria, on 17-19 January 2018.

This article is published in the section Practical Theology of the Society for Practical Theology in South Africa. 
(2001, 2014), Nadar (2009) and Owino (2012) on the Mighty Men Conference in South Africa in particular. Rather, it is to highlight that although discourses such as alternative masculinities and liberated masculinities provide different routes from the supposedly problematic hegemonic masculinities and toxic masculinities, current and prevalent conceptualisations of transformation in these discourses can also be very limited in their thinking on what transforming masculinities is or can be.

Specifically, I put forth the argument that masculine ideals in general eschew mobility and fluidity and, therefore, even in their liberatory forms, end up restricting the greater possibility of transformative action from which their idealisations arise. I propose, instead, that we reinscribe discourses of Christian masculinities with the notion of nomadic subjectivity, espoused by Braidotti (1994; 2011), as a form of transpositional praxis of being in order to expand our linguistic repertoire of what counts as transformative masculinities. Such a shift in focus, as I demonstrate, has the propensity to aid us in constructing and implementing creative and imaginative programmes of engaging religious men in rethinking scripts of masculinities.

I propose that the idea of nomadic masculinities is best suited to not only challenging exalted, hegemonic and toxic masculinities, but also to not proscribing the anterior of ideas of transforming masculinities in general. Therefore, in working with the figuration of the nomad as instructive for contemporary discourses of religious masculinities, my general aim is to highlight the productive side of bordercrossing and impress upon us that the nomad does not stand for complete detachment from all roots or a desire for 'compulsive displacement', but rather, as Braidotti argues, what the nomad stands for is 'the kind of subject who has relinquished all idea, desire, or nostalgia for fixity' (1994:22). In developing my argument, I begin with a short description of my general approach to research on masculinities and Christianity in South Africa so far, followed by a definition of the concept of nomadic subjectivity as explained by Braidotti. Then I present a discussion on why this concept matters for theology and studies in masculinities, and end with an example of a Christian men's organisation that I believe has already begun to engage with the figuration of nomadic masculinities in very productive ways for critical Christian masculinities in South Africa.

\section{Masculinities and Christian men's organisations in South Africa}

Judging from the number of publications on the topic of religions and masculinities in South Africa (and the Southern African Development Community region in general) that we have witnessed in the past two decades, it is fair to say that significant attention has been given to issues of masculinities and religions (Chitando \& Chirongoma 2012; Nadar 2009; Owino 2012; Ratele 2002; 2016; Togarasei 2012; 2013; Van Klinken 2013). In adding my own voice into the pool of scholarships on the topic (Dube 2015; 2016a; 2016b), my primary research approach has so far focused on answering the following question: what roles can Christian religious discourses on masculinities play within the broader national processes of gender transformation regarding masculinities that are currently taking place in post-apartheid South Africa? That is, while it might be easy to assume both the positive and negative impacts of religions and masculinities in South Africa, my interest lies in unpacking such assumptions and examining the generative capacities of Christian religious discourses of masculinities to positively affect the broader public sphere discourses on gender and, specifically, masculinities (Dube 2012; 2014).

To that end, and as part of contributing to the 'liberated masculinities' discourse, one of my main objectives has been to demonstrate how conservative religious right men's groups, such as the Mighty Men Conference in South Africa and the Promise Keepers in America, have the capacity to contribute to a generative masculinities discourse because of their largely relational construction of self-transformation with respect to the public sphere (Dube 2014; 2015; 2016b). In achieving this objective, I have drawn on the works of Newton (2005) on the Promise Keepers in America and JeanFrancois Roussel (2003) on Roman Catholic masculinity in Quebec, Canada. Both these authors highlight the possibility of Christian men's movements having the capacity for transformative work on masculinities despite their largely conservative religious ideologies, especially in the case of the Promise Keepers. This is an argument which I have then sought to elucidate in my work comparing the Mighty Men Conference in South Africa with the Promise Keepers in America (Dube 2016b). That is, in contrast to the highly publicised cases of conservative religious gender values associated with these organisations, which are important to highlight, I have endeavoured to demonstrate the extent to which these Christian men's organisations have a positive role to play in challenging prescriptively normative and proscriptively 'hegemonic' notions of masculinities despite the seemingly intransigent nature of the religious discourses within which they function (discursive practices which traditionally promote particularly negative gendered discourses of masculinities).

It is important to note that my aim has not been to defend the rhetoric and practices of conservative Christian men's organisations, such as the Mighty Men Conference, in their uncritical self-proclaimed forms, but rather to ask questions about how such an organisation's response to the perceived 'crisis of masculinity' informs its ideology and how scholars of masculinity can better understand this ideology in their efforts to engage such organisations meaningfully and constructively. In fact, the response to the 'crisis of masculinity' within Christian men's organisations has been varied, but this variety often gets lost through a focus on the loudest voices of the most publicly prominent organisations, such that it appears as if the general Christian men's voice in South Africa around issues of masculinities is largely a 
regressive and oppressive one. However, if we look at discourses of Christian masculinities from the perspective of the Deluzean rhizome (Deleuze \& Guatarri 1987), where nodes intersect at multiple points, we find more dynamism and fluidity with respect to constructions of masculinities that are constantly in conversation with one another within an individual, amongst individuals in the same group, as well as amongst different individuals in different groups.

This last point notwithstanding, it is also true that, from a certain perspective, an organisation such as the Mighty Men Conference may seem to not have the capacity to engage broader notions of masculinities. Such a lack of capacity may be precisely due to the myopic focus of this organisation's transformation work and also because of the primacy and centrality of the language of the doctrine of personal salvation on which it is founded. That is to say, both the language and religious doctrine prioritise self before others and only in relation to the one 'Supreme Other'. Arguably, such an insular perspective is driven mostly by an evangelical language of transformation that sees transformation in terms of 'personal salvation' and as a personal choice - a matter between oneself and God foremost, even though one is ultimately expected to 'witness' to others as a way of demonstrating their transformation. As such, the work of transformation of this particular Christian men's organisation is mostly felt in the immediate contexts within which most of these men live - namely, immediate families and churches, and very little beyond those contexts.

For example, in an interview for the television show Carte Blanche, Angus Buchan, leader of the Mighty Men Conference, which is arguably the leading Christian men's organisation in South Africa at the moment, is noted as saying:

Man's masculinity in the world today, in this 21st Century, is being eroded and broken down. And young men - some young men - don't know what a man is supposed to be! There are no role models, no mentors to look up to. What is a man supposed to do? How is he supposed to act? ... And so what we did was - I believe, not we, but the Lord - restored masculinity. (Nadar 2009:553-554)

Buchan's statement makes it clear that there was once, supposedly, a time when masculinity was not eroded and men knew how to be men. Therefore, according to Buchan, as part of the response to the so-called 'crisis of/in masculinity', Christian men have needed to return to a conservative hegemonic masculinity that stands in sharp contrast to the supposed 'feminisation' of the public sphere. Moreover, such a return is premised on individual men taking a personal lead in such restorations (albeit within a community of believers). Furthermore, as Buchan's statement reiterates, God is ultimately responsible for such restoration of masculinities. In this sense, the Mighty Men Conference's view might be referred to as proscriptively 'traditional' or prescriptively 'conservative' and, therefore, seemingly intractable.

In contrast, it is easy, for example, to pitch IMBADU Men's Project's (IMBADU) view below, which is a Christian men's group based in Cape Town, against that of the Mighty Men Conference's view above as holding the so-called liberated view of religious masculinities. IMBADU defines itself as:

a project for men. We are concerned for men. We believe that in the current South African situation many men are insecure about themselves and relationships with other men and women and children. There is a very high degree of violence, mostly committed by men. But while we are concerned for men, this concern is not an exclusive one but inclusive, including a concern for women and children, and embracing a diversity of masculinities. (IMBADU 2017:n.p.)

It is important to note in this self-definition that while acknowledging the important role that men have to play in examining themselves within the contemporary South African discourse on gender transformation, IMBADU does not construct the significance of this role in conservative gender terms or see it only as a men's issue that requires a hands-off approach from women, as conservative Christian men's groups such as the Mighty Men Conference do in their hierarchical constructions of conservative reclamations of a singular masculinity. In that sense, we might refer to IMBADU's approach as 'progressive' or 'liberated' and, therefore, ostensibly desirable.

While such a comparison would provide an easy contradistinction, part of what I am interested in when I engage in research on an organisation such as the Mighty Men Conference with respect to masculinities is whether their various versions of transforming men necessarily delimit the capacity of this organisation to have a stronger and broader social impact on social transformation focused specifically on a set of transformed gender norms. Consequently, the larger question then, which is not new per se, is whether Christian men's organisations in post-apartheid South Africa have the capacity to drive social change in ways that affirm both the constitutional democracy call and the Christian theological call for social justice. While the Mighty Men Conference's conservative approach highlighted above is problematic from a certain perspective, it is interesting to note how it centres on individual self-transformation aimed at giving responsibility to men to engage their own processes of transformation in light of their relationality to the changing world with which they are now faced. Given the limitations of a self-centred notion of transformation, one can also ask the following question: is it possible to see beyond this limitation in pursuit of a more inclusive project of transforming masculinities that sees even in the Mighty Men Conference a process that, while seemingly limited in its imaginative capacity, has the potential to shift perspective and elicit constant hope for transformation in Christian men?

As a way of attempting an answer to the question, I will later describe a process used by IMBADU that I believe has the potential to translate to other Christian men's organisations and, thereby, make it possible to engage more in what I call nomadic forms of practices of masculinities. However, before engaging that answer, I turn to a description of nomadic masculinity in order to highlight this concept as a site of 
possibility for going beyond the current given alternatives in discourses of critical masculinities. I turn to nomadism because I believe that the concept has potential to push even my own openness to greater capacity with respect to how I engage Christian men's groups that do not immediately share my perspectives on gender norms transformation.

\section{Rosi Braidotti and nomadic subjectivity}

The New World Encyclopedia (2015) defines nomadism as:

distinguished from migration, which involves a major and permanent move from one location to another. Nomads, on the other hand, move periodically or cyclically, usually returning to their original location at various times. (n.p.)

Consequently, the insistence on mobility and a refusal to be affixed or confined are hallmarks of nomadic subjectivity and, heuristically speaking, they provide the means to break out of the limited options of identity constructions amongst which we are usually forced to choose as our home positions from which to speak. Put simply, nomadism challenges the idea of home as static and unchanging. Hence, as a tool for thinking gendered subjectivity and the politics of change in particular, nomadism challenges the normative Archimedean perspective privileged by a constant search for fixity.

Braidotti captures the fluidity of nomadism well when she insists that 'nomadism consists not so much in being homeless, as in being capable of recreating your home everywhere' (1994:16). So, rather than simply jettisoning all hegemonic masculinities as empty possibilities for transforming masculinities and elevating discourses of liberated masculinities or alternative masculinities as purer categories for meaningful change, a nomadic discourse of masculinities would seek first to understand the journey of how we have gotten to where we are with respect to masculinities (or how we have created our 'home') and how we might reinscribe our current position through a cyclical return to and anticipation of some of the ideals of masculinities that are both posterior and anterior to the current hegemonic ones (or how we might change our perspectives).

Such a nomadic approach to discourses of transformation stands in sharp contrast to the practice of deriving social change from a position of pure opposition usually taken up by both those who seek to transform the so-called traditional masculinities and those who seek to maintain and protect such masculine identities. That is, in relation to the discussion of the Mighty Men Conference and IMBADU above, rather than leaving a comparative analysis of Christian masculinities discourse at the level of contrast, a nomadic masculinity approach pushes us to find those rhizomatic nodes of connection so that we may have a better picture of what informs prevalent conceptions of masculinities beyond simply the given norms or proposed visions. This means foregoing simplistic contrast work as definitive and really pushing ourselves outside the realm of fixity and surety into the land of travelling concepts. Such a shift in thinking is reflective of my own scholarly journey as well, where I have slowly moved away from a prescriptive approach to dealing with transformative masculinities to an indicative and evocative one, hence the choice of nomadism as a point of interrogation in this article.

In her work, which generally examines the relationship between nomadic theory and feminist concerns about difference, Braidotti $(1994 ; 2011)$ offers the concept of nomadic subjectivity as another tool for thinking about difference and its potential for agentic subjectivity. Moreover, she does so without devolving into prescriptive universalism - which is a very difficult political project indeed given that in social justice contexts we wish to clearly name the problem and identify the solution in terms that demonstrate how what is suggested as new is different from what has come before it. In Practical Theology, this kind of liberatory thinking is demonstrable in the ways in which we frame, in cyclical terms, the interrelation between the questions: what is going on?, why is it going on?, what ought to be going on? and how might we respond? (Osmer 2008). That is, in the end we envisage a point where there are clear answers to the problem at hand and, however contextual the methods used, we can come out with a practical answer that can be applied universally. It is in this same sense of having a practical answer that liberated or alternative masculinities tend to be demonstrated as different from toxic and exalted hegemonic masculinities if the former are to supposedly shift the accepted norms. Consequently, although starting from a position of demonstrable openness, the praxis of liberatory discourses of transformation ends up actually being antonymic.

Wishing to address this paradox of negotiating difference without falling into a limited binary understanding of subjectivity that would only leave us with a linear narrative of progress (which much of postmodern theory has successfully challenged), Braidotti (1994) defines nomadic subjectivity as:

a figuration for the kind of subject who has relinquished all idea, desire or nostalgia for fixity ... [it] expresses the desire for an identity made of transitions, successive shifts ... without and against an essential unity ... (pp. 22-23)

That is, as a 'form of political resistance to hegemonic and exclusionary views of subjectivity' (p. 23) or fixity, the notion of nomadology represents not only a further step away from proscriptive hegemony, but also signifies openness to even greater potentialities of liberation than what we may currently hold. Consequently, it is this notion of nomadic subjectivity as resistance to the structures of stricture that I highlight as useful for rethinking discourses of Christian masculinities, and not only against problematically hegemonic forms but also liberatory ones. For, as I have alluded already, even liberatory discourses of masculinities are susceptible to subscribing to a fixed notion of transformation and can end up being caught in the trap of 
limited imagination. That is, a transformed man should be a specific being who acts in a specific way.

In fact, one of the major criticisms of the general discourses of critical masculinities that I am putting forth here - granted their openness and critical perspective - concerns their overreliance on the Archimedean politics of having the fulcrum and lever long enough to shift the discourses of masculinities in the opposite direction - that is, from one solid position (oppressive and hegemonic) to another solid position (alternative and liberated). This perspective is, of course, subtended in the other camp of exalted and hegemonic masculinities by the overreliance on the politics of melancholia, nostalgia and a general desire for the maintenance of the status quo, where we are always reaching back at what was supposedly good and proper - which I am saying is also just as problematic. Subsequently, the perspectives of critical discourses of masculinities generally espoused as progressive tend to suffer the opposite fate, but just as prescriptive and proscriptive, of languishing in the state of melancholia, and one that presupposes a utopian idea of masculinities and the new man who has shed his old skin, and is supposedly unencumbered by the weight of 'tradition' - because tradition is so, oh, so toxic!

Therefore, in order to stress the affirmative nature of critical thought that challenges the static constructions by both traditional hegemonic masculinities and the critical alternative masculinities, I argue for the idea of nomadic masculinities, where nomadic masculinities represent a set of discursive practices and processes, whose central tenet 'is to reassert the dynamic nature of thinking and the need to reinstate movement at the heart of thought' (Braidotti 2011:7). For Braidotti, the nomadic subject is a utopian figuration that is not about displacement but about a discursive freedom from dominant narratives. For my purposes, this utopian figuration seeks freedom from dominant narratives of masculinities that come from both the conservative and the liberal traditions and asks, instead, for room to expand one's thinking and acting. Taking cue from Braidotti's construction of nomadism, I contend that the concept of nomadic masculinity can serve as a useful formulation for exploring some of the ways in which we might rethink the 'how', in our African context, of interrogating the relationship between normative identities of masculinities as resistant to change on the one hand and critical subjectivities of masculinities as agents of change on the other hand.

Such a reconfiguration of masculinities as nomadic is especially significant to interpolate in the context of a postcolonial Africa defined increasingly by labile discourses of masculinities that are constantly shifting shapes. Moreover, it might begin to offer a way out of Kopano Ratele's recently stated conundrum in Liberating Masculinities (2016) that ' $[t]$ here seems to be little movement in changing gender relations or representing the benefits of progressive masculinities to men' in South Africa (p. 70). According to Ratele, this 'cheerless state of masculinities' is a result of the following: firstly, a lack of convincing men that they are gendered; secondly, a lack of clear connection between boys' and men's lives and that of the larger socio-political context; thirdly, a lack of cultural translation between researchers and their male 'subjects'; and, fourthly, an easy 'acontextual and uncritical' application of concepts, methods and languages from elsewhere with little consideration for the actual and localised realities of men's lives (pp. 70-71). While not completely jettisoning the work of critical masculinities scholars, Ratele is keen to challenge the myopia of current research on masculinities in South Africa, thus pointing to the ways in which even liberatory discourses of masculinities such as critical masculinities studies can be blind to their own forms of marginalisation - especially with respect to unexamined conceptualisations of African masculinities that use a single brushstroke with which to paint African men. I have also made a similar argument with respect to the representations of black men in academic scholarship on masculinities in post-apartheid South Africa (Dube 2016a).

For Ratele (as well as myself), since power and marginalisation play a key role in terms of what kind of scholarship gets produced on men due to their power differential, this differential cannot be ignored in the context of a country like South Africa due to the intersection of colonialism, capitalism, racism and heteropatriarchalism in particularly insidious ways. In other words, as theorist Judith Butler has argued in a chapter entitled 'Contingent Foundations: Feminism and the Questions of Postmodernism' (2001:639), power and subjectivity function in ambivalent ways and the subject (religious Christian man in this case) is neither pure ground nor pure product (both of which privilege assumedly stable essences of being), but a permanent possibility of certain resignifying processes. In these resignification processes (or the possibilities for different configurations, refigurations and reinscriptions in Braidottian terms) exists the potential for different religious masculinities and subjectivities to emerge. Indeed, by insisting on dynamism, constant change as well as processual thinking, nomadic masculinities can be said to exist in excess of the limitations of any religious context and politics. Consequently, this is why I argue that nomadic masculinities offer a great heuristic space for examining the capacities for non-linear transformation within the supposedly intransigent spaces of religious praxis.

Indeed, from the perspective of nomadic masculinities, processes of masculinities are never complete projects but subjectivities that are informed by transposition and metamorphosis. Metaphorically speaking, nomadic masculinities are a kind of Kafkan dynamism that acknowledges the latent power of all masculinities to transform their potential (energy) into a kinetic materialism that has the ability to actuate seismic plasticity on contemporary human ethical capacity. In this sense, nomadic masculinities cannot languish in despair precisely because the process of becoming is always on and always changing. There is no expectation for immediate change bound by the limited realities of the present, but a hope for an ongoing 
sense of change that is always related to other phenomena that are past, present and future.

That is, to invoke Deleuze and Guattari's notion of transversality in Nomadology: The War Machine (1986), transformation is never a complete process but a deterritorialised tendency towards the virtual (or where one aims to go - the real but not actual or the ideal but not abstract). In this sense, change is not indexed by a clear opposition to a past sense of self, but rather by the interrelation between the past, present and future selves of which each man is composed, so to speak. Such an understanding of masculinities as always possibilities has a capacity to trouble our projects of liberation in ways that push us in directions we have yet to imagine. So, rather than simply assuming that we have the right alternatives and all we need to do is to do the right things to convince men of how to get there, nomadic masculinities question such a formulaic understanding of subjectivity as a linear process.

\section{Nomadism and Christian theology}

What is also particularly poignant about Braidotti's nomadic subjectivity when applied to Christian theology is that it privileges discursive freedom from dominant narratives, rather than strict displacement, as foundational to deep transformation. In Resurrection City: A Theology of Improvisation (2012), Peter Goodwin Heltzel suggests a good understanding of how such a discursive freedom functions as a foundation for deep transformation in the story of Abraham and refers to this as nomadic theology (2012:26). Specifically, Heltzel notes that when God calls Abraham to leave Ur, Abraham hears the call and responds. Moreover, the only thing that Abraham 'knows with surety is the promise of God' (p. 26). That is, as Braidotti argues with respect to nomadic subjectivity, there is no guarantee in nomadic subjectivity except the hope of possibility for change and it is this hope of possibility that needs to be nurtured constantly.

Furthermore, despite the lack of surety, Geiser (2013) sees in nomadic theology a chance for seeing things anew - the freedom to explore. Geiser (2013) expressly argues that:

Theology that becomes nomadic will keep traveling constantly in its mind, moving from one place to the next, even if staying at home. Too much theology is written without the experience of travel. Too much theology has stayed at home without allowing the bigger world move in. The result of theology conceived in this way, staying at home and keeping the world outside, is usually a kind of sedentary stability, mono-cultural boredom, and textual uniformity. (p. 348)

From this perspective, the advantage of a nomadic theology lies in its ability to be fully adaptable and relevant such that it can have full impact on the lives and cultures of those who embrace it.

At face value, this preceding argument might sound rather familiar and almost hackneyed to those of us used to postmodern discourses of fluidity and critiques of meta-narratives. However, the ability to draw heavily on discursive freedom in order to produce positive and lifeaffirming identities of nomadic selves rather than simply dissolving into the problematic choices of identity proffered to us by virtue of our limited statuses is not an easy one to achieve. More often than not, it is easier to remain in our galvanised theological borders than to seek to transgress those borders in search of less certain and secure senses of identities or beings. Within the most prevalent discourses of Christian masculinities, such a lack of nomadic subjectivity can be easily gleaned in the conservative men's organisations such as the Promise Keepers in America and the Mighty Men Conference in South Africa. However, as per Ratele's argument above, this is not to say that liberatory-minded organisations, despite their avowedly open processes, cannot be subject to a less than nomadic understanding of Christian masculinities.

Indeed, nomadism represents a paradox in that it does not categorically eschew the notion of belonging but warns us against letting our guard down such that belonging becomes a form of categorical exclusion. This is easier to see with respect to the so-called hegemonic forms of masculinities. However, as I have maintained so far, alternative masculinities also run the risk of prescribing the supposed right script of performing how one should be deemed in being a so-called liberated man. If, consequently, one does not perform according to this particular script, then one can be quickly labelled as problematic or, even worse, toxic and refractory. From a nomadic masculinity perspective espoused here, such an approach to masculinities, where one belongs or one does not, fails to acknowledge that belonging is never a fait accompli.

Therefore, in seeking to affirm a position of critical engagement with borders, as well as their seeming necessity, and the possibilities they foreclose, nomadic masculinities represent a paradox for discourses of gender justice. To put it in the form of a question on masculinities: if hegemonic and toxic masculinities are problematic, are not critical masculinities or liberated masculinities or alternative masculinities better bases on which to found new practices of masculinities? Are not alternative masculinities better in addressing the violence of hegemonic masculinities? is it not necessary, from a social justice perspective, to ground oneself solidly in the camp of alternative and liberated masculinities if we are not to lose ground on the gains made in terms of challenging hegemonic patriarchy so far? In other words, why insist on nomadic masculinities?

From Geiser's (2013) perspective noted above, even liberatory discourses of change can gain something from shifting perspectives. Therefore, nomadic masculinities provide an opportunity for alternative masculinities and liberated masculinities to also move beyond their self-understanding (however progressive) in order that they may remain constantly relevant. From Braidotti's perspective, what nomadic masculinities offer is a constant flame of hope for the possibility of change that might otherwise be easily 
extinguished if we focus solely on observable change or result-oriented praxis that pitches 'toxic hegemonic man' too easily against 'liberated alternative man' in a game of winner takes all.

\section{Nomadic Christian masculinities in practice}

To return to IMBADU, which I believe is at least one Christian men's organisation that is already embracing the type of theology and practices of masculinities that I call nomadic, we can note some practical ways in which thinking of masculinities in nomadic terms has impacted this organisation's approach to transforming the lives of the men in its programmes. In describing IMBADU's process of engaging men, I would venture that the organisation's rationale is one informed primarily by a focus on shifting men's understanding of power from power as domination to understanding power as empowerment through a process of considering masculinity in light of the cross, discipleship and resurrection. This is where a man is discipled to hold a liminal understanding of himself as not only vulnerable but also subject to failure and admitting feelings of insecurity, fear, guilt, grief and sin and resurrected into a new man through the process of discipleship.

This power rationale is captured well on the organisation's description of the concept of journeying as consisted of experiencing, exploring and improving:

... experiential: we are encouraging men to share their own experience, rather than discussing issues, defending positions from a 'head space'. This is done by inviting men to reflect on a range of different topics with relevance to masculinity and share their own experience with others in small groups.

... explore: we don't want to make assumptions about ourselves and others, but rather explore, find out, ask questions, hold the tension of not having (immediate) answers, venture into the unknown.

... improve: accepting that we are all on a journey, there is room for improvement, growth, development which we seek consciously. This also means facing the sides within us that may need attention. (IMBADU 2017:n.p.)

According to this power rationale:

one should not expect a certain outcome (like in a cooking or mechanics course), the 'perfect man' after the conclusion of a course, weekend, etc. It is all part of a lifelong learning process. However, the direction that is taken is important. (IMBADU 2017:n.p.)

In particular, as I was able to observe through participating in a number of sessions in June 2015, the facilitators' use of art to engage men in this process of journeying, where we, as men, were all regarded as on the way, emphasised that 'nobody has arrived, there is no expert, we are all learning'. In one of the sessions in which I participated, for example, we were asked to use drawings to represent key moments in our lives that we thought deeply informed our multiple conceptions of ourselves as men. By sharing the artistic representations of our self-understanding with others, the idea was that each man could begin to see similarities of life trajectories and influences within one's own life and in the lives of other men and, thereby, allow himself to journey with others in the process of self-analysis and revelation. The idea being that positive affirmation through sharing with others, not a perfect sense of self but a broken and vulnerable one, is a key aspect of transforming men. This focus on shared experiential knowledge, which culminates in situating oneself within a matrix of influences, has the advantage of concretising experiences of transforming masculinities through a platform of shared experiences from which the interrogation of intersecting experiences can begin without being imposed from the top-down.

In other words, by letting men go through this reflexive process of self-definition and, through that reflection, come to terms with the limitations of their own self-understanding, IMBADU creates a space of minimal judgement and reflects the Christian understanding of Christ as compassionate, thus allowing men to see themselves from a different and compassionate position than that they would traditionally privilege through notions of deficiency, for example, which are then over-compensated through notions of extreme lack of vulnerability. Admittedly, this process differs from individual to individual and while the facilitation process does not completely cater for this differential experience in the ideal way that it could, the general aim is for the men to take this as a tool with which they can practice selfexamination for the rest of their lives. The idea is that the men journey through their experience and constantly explore ways of improving who they are in relation to the figure of Christ who was also broken, but in that brokenness achieved newness through resurrection. Here, self-transformation does not only lie outside in a God that transforms 'sinners' as in the traditional discourse of conservative Christian men's organisations such as the Mighty Men Conference, but is also an internal process of self-understanding, self-critique and self-acceptance that is informed by a multiplicity of forces.

In our post-colonial and post-apartheid South African context that is still ironically defined by the fixity of ideas, it is imperative to stress nomadism as a useful political artifice for understanding the process of positively reinscribing subjectivity, even though, admittedly, nomadism as real-life experience also carries with it the capacity for further injury in very material ways. Notwithstanding this accession of a materialist reality check, nomadic masculinities (as espoused here) challenge this game that can only be played one way and engage transversal feminist politics which draw from an understanding that intersectionality is always at play and is a necessary element of doing transformative work, be it on self or otherwise.

\section{Conclusion: Trails of a striated nomadology?}

By way of reiteration, I would argue that there is one major point arising from the foregoing analysis. It is the observation 
that, rather than simply assuming that all Christian discourses of masculinities pander to the dominant narrative of loss within the discourse of the 'crisis of masculinity', we should look at the narratives proffered by religious men's organisations as ambiguous at best. This is where such religious men's organisations renegotiate masculine gender performance through reconfigured scripts of masculinities informed by a variety of sources, including both religious and non-religious discourses of masculinities. It is this ambivalence of nomadic subjectivity, which locates its characters both outside the terms of the dominant narratives of subjectivity and inside the spaces of mimetic refiguration, that allows certain religious men to challenge both the assertions of prescriptive traditionalism and liberated masculinities, where prescriptive traditionalism would paint them as upholders of a problematic patriarchal discourse of masculinities and liberated masculinities would paint them as not liberated enough because of their religious belonging. While 'nomadism is, of course, only one of a myriad ways to look at these transitions, and it is by no means exhaustive' (Tamboukou 2004:n.p.), it is at least a departure point away from the conceptual violence of the masculine ideal.

Although hegemonic notions of masculinities and institutionalised formulations of religious traditions lend themselves to being read as exercises in consolidating an identification with the privileged category 'man', they do not, nonetheless, represent coherent unified systems that are simply reproducible across time and space (Howson 2006:53-55). Instead, what this foray into nomadic masculinities reveals is both a problematic and fruitful side to the discourses of masculinities, highlighting the ways in which some religious men's organisations use multiple configurations of masculinities to challenge other forms of masculinities currently in fashion and which they also deem as socially and morally corrupt. As such, the elucidation of the concept of nomadic masculinities within specific sociohistorical contexts can prove to be a very useful heuristic tool for understanding the complexities of Christian religious masculinities. To put it differently, if 'man' as a moniker or appellation is understood to be a plateau of patriarchal inscriptions in particular, then it can only make sense that its reinscription into reconfigured subjectivities through nomadic experiences will result in the transposition of men's agency, where masculine identities shift from positions of men being simply citizens of a single camp to ones of having the capacity to actually further their lives by being able to affirm their ability to 'rename' themselves as particular kinds of men in relation to multiple points of being - that is, not just plateauliths.

\section{Acknowledgements}

The author would like to thank the SPTSA for the invitation to deliver the address. I am also grateful to the respondent, Elijah Baloyi of UNISA, as well as the rest of those in attendance, for helpful insights and comments on the paper. A special thank-you is also due to Elina Hankela for all her insights and support with respect to the keynote address and the article revision. The published version of the article intentionally retains the personal character of its original manifestation, but some points have been further developed in the interest of better contextualisation and clarification.

\section{Competing interests}

The author declares that he has no financial or personal relationships which may have inappropriately influenced him in writing this article.

\section{References}

Amoah, E., 1997, Where God reigns: Reflections on women in God's world, Sam Woode Publishers, Accra.

Braidotti, R., 1994, Nomadic subjects: Embodiment and sexual difference in contemporary feminist theory, Columbia University Press, New York.

Braidotti, R., 2011, Nomadic theory: The Portable Braidotti, Columbia University Press, New York.

Butler, J., 2001, 'Contingent foundations: Feminism and the question of "postmodernism"', in D. Juschka (ed.), Feminism in the study of religion: A reader, pp. 629-647, Continuum, New York.

Chitando, E. \& Chirongoma, S., (eds.), 2012, Redemptive masculinities: Men, HIV, and religion, World Council of Churches Publications, Zapf Chancery Publishers Africa, Kijabe, Kenya.

Deleuze, G. \& Guattari, F., 1986, Nomadology: The war machine, transl. B. Massumi, Semiotext(e), New York.

Deleuze, G. \& Guattari, F., 1987, A thousand plateaus: Capitalism and schizophrenia, transl. B. Massumi, University of Minnesota Press, Minneapolis, MN.

Dube, S.I., 2012, 'Masculinit(y)ies and religion(s)', in J. Laker (ed.), Canadian perspectives on men and masculinities: An interdisciplinary reader, pp. 202-221, Oxford University Press, Don Mills, ON.

Dube, S., 2014, 'The promise keepers Canada and Christian relational masculinities', Religious Studies and Theology 33(2), 172-193, https://doi.org/10.1558/rsth v33i2.173

Dube, S., 2015, 'Muscular Christianity in contemporary South Africa: The case of the mighty men conference', HTS Teologiese Studies/Theological Studies 71(3), Art. \#2945, 9 pages. https://doi.org/10.4102/hts.v71i3.2945

Dube, S., 2016a, 'Race silence: The oversignification of black men in "the crisis of/in masculinities" in post-apartheid South Africa', Acta Academica 48(1), 72-90, aa48i1.4. https://doi.org/10.18820/0587-2405/aa48i1.4

Dube, S., 2016b, 'Race, whiteness and transformation in the promise keepers America and the mighty men conference: A comparative analysis', HTS Teologiese Studies/ Theological Studies 72(1), a3476. https://doi.org/10.4102/hts.v72i1.3476

Du Pisani, K., 2001, 'Puritanism transformed: Afrikaner masculinities in the apartheid and post-apartheid period', in R. Morrell (ed.), Changing men in Southern Africa, pp. 157-176, University of Natal Press, Zed Books, Pietermaritzburg, New York, NY.

Du Pisani, K., 2014, 'Palatable patriarchy? Angus Buchan, the "mighty men" and masculinity', paper presented at the European Social Science History Conference, Vienna, Austria, 23-26 April, pp. 1-31, viewed 23 October 2014, from https:// conference.socialhistoryservices.org/esshc/2014/userApi/downloadPaper/579

Geiser, H-P., 2013, The community of the weak: Social postmodernism in theological reflections on power and powerlessness in North America, Wipf \& Stock, Eugene, OR.

Heltzel, P.G., 2012, Resurrection city: A theology of improvisation, Eerdmans Publishing, Grand Rapids, MI.

Howson, R., 2006, Challenging Hegemonic masculinity, Routledge, London.

IMBADU Men's Project, 2017, Centre for Christian spirituality: Silence and solidarity, viewed 14 June 2017, from http://christianspirit.co.za/imbadu-mens-project/

Kanyoro, R.A.M. \& Njoroge, J.N. (eds.), 1996, Groaning in faith: African women in the household of God, Acton Publishers, Nairobi.

Nadar, S., 2009, 'Palatable patriarchy and violence against wo/men in South Africa: Angus Buchan's mighty men's conference as a case study of masculinism' Scriptura 102, 551-561. https://doi.org/10.7833/102-0-614

Newton, J., 2005, From panthers to promise keepers: Rethinking the men's movement, Rowman \& Littlefield, Oxford.

Njoroge, J.N. \& Dube, M.W., 2000, Talitha cum! Theologies of African women, Cluster, Pietermaritzburg.

'Nomad', 2015, New World Encyclopedia, viewed 17 January 2017, from http://www. newworldencyclopedia.org/p/index.php?title=Nomad\&oldid $=989416$

Oduyoye, M.A., 1990, Who will roll the stone away, WCC, Risk Books, Geneva.

Oduyoye, M.A. \& Kanyoro, R.A.M. (eds.), 1992, The will to arise: Women, tradition, and the church in Africa, Orbis Books, New York.

Oduyoye, M.A. \& Kanyoro R.A.M. (eds.), 2001, Talitha Qumi: The proceedings of the convocation of African women theologians, Daystar Press, Ibadan. 
Osmer, R., 2008, Practical theology: An introduction, Eerdmans, Grand Rapids, MI.

Owino, K., 2012, 'The mighty men conference as a "safe space" for "born again" men to express conflicting masculinities?', Journal of Gender and Religion in Africa 18(2), 65-84.

Phiri, I., Govinden, D.B. \& Nadar, S., 2002, Her-stories: Hidden histories of women of faith in Africa, Cluster, Pietermaritzburg.

Ratele, K., 2002, 'Contradictions in constructions of African masculinity', News from the Nordic Africa Institute, No. 2, May, 2-5.

Ratele, K., 2016, Liberating masculinities, HSRC Press, Cape Town.

Roussel, J-F., 2003, 'Roman Catholic religious discourse about manhood in Quebec: From 1900 to the Quiet Revolution (1960-1980)', The Journal of Men's Studies 11(2), 145-155. https://doi.org/10.3149/jms.1102.145
Tamboukou, M., 2004, 'Nomadic trails in the unfolding of the self', Spaces of Identity $4(2)$, n.p.

Togarasei, L., 2012, 'Pauline challenge to African masculinities: Reading Pauline texts in the context of HIV/AIDS', Acta Theologica 32(Suppl. 16), 148-160, viewed n.d., from http:// www.scielo.org.za/scielo.php?script=sci_arttext\&pid=S1015-87582012000300010 \&lng=en\&tlng=en

Togarasei, L., 2013, 'Christianity and hegemonic masculinities: Transforming Botswana hegemonic masculinity using the Jesus of Luke', Scriptura: Journal for Contextual Hermeneutics in Southern Africa 112(1), 1-12. https://journals.co.za/content/ script/112/1/EJC146667

Van Klinken, A., 2013, Transforming masculinities in African Christianity: Gender controversies in times of AIDS, Ashgate, Farnham. 